eyes with corneal lesions were photographed. The surface area of each corneal ulcer was measured from the photographic image. Secretions from all of the eyes also were cultured weekly to determine whether the antibiotic treatment successfully eliminated $M$. bovis. Calves were weighed weekly to determine the effects of the drug therapy on weight gains. At the end of the study, all $M$. bovis isolates were tested for susceptibility to the tetracyclines and the nitrofurans.

Corneal ulcers occurred in 102 calves. By the 22nd day of the study, fewer calves in the OTC group had corneal ulcers than in the other two groups. OTC calves had the most rapid healing rate and the lowest incidence of multiple ulcer recurrences. The rate of $M$. bovis isolation from the eyes of this group was significantly less than from the other two groups. Calves in the FZ group had more severe ocular lesions and a greater number of multiple ulcer recurrences than the OTC group calves, but were significantly better off than the controls. The $M$. bovis from the OTC group did not become resistant to either furazolidone or tetracycline, whereas the $M$. bovis from the FZ group calves showed a slight increase in resistance to the nitrofurans.

The average weekly body weights and weight gains were similar for the three treatment groups. Despite the clear therapeutic effectiveness of oxytetracycline over that of furazolidone, a cost analysis of the treatments (including the labor required to gather the cattle and administer the drugs) indicated that the OTC treatment had the highest cost of the three groups.

The second study compared oxytetracycline and penicillin treatments. Beginning on June 10, 119 calves were randomly assigned to one of three groups: 39 designated as OTC, 40 Pen, and 40 nontreated controls. The calves were kept in a common pasture during the entire summer and were examined three times daily as in the first study.

Treatments were administered to the calves of the OTC and Pen groups after an initial 4-day observation period. Affected calves of the OTC group were given two intramuscular injections of the long-acting oxytetracycline formulation $(20 \mathrm{mg} / \mathrm{kg}) 72$ hours apart. All of the OTC calves then were fed 2 grams per head per day of oxytetracycline in alfalfa pellets for 10 days. Calves of the Pen group that had corneal ulcers were treated with three daily subconjunctival injections of procaine penicillin $G$ (300,000 IU per injection). In both groups, treatments were administered to individual calves again if they developed a new corneal ulcer in either eye, or if the existing ulcer worsened. Calves of the control group remained untreated for the entire summer.

The prevalence of pinkeye was significantly reduced in the Pen and OTC groups within 12 days after treatment. OTC calves had significantly fewer ulcers than did calves of other two groups. Between days 16 and 44, the prevalence of pinkeye in the OTC calves ranged between 0 and 2 cases, whereas the penicillin-treated calves and controls ranged from 3 to 8 and 19 to 22 cases daily, respectively. Oxytetracycline and penicillin groups had significantly fewer active cases of pinkeye in individual calves than the controls. The two drugs were similar in effectiveness for the individual case. The healing times and average ulcer size for corresponding numbers of days after treatment were similar in the OTC and the Pen groups. The rate of $M$. bovis isolations from the eyes of the OTC group calves was significantly lower than that of the other two groups.

The results of the second study strongly suggest that a combination of "blitz" therapy with a long-acting formulation followed by short-term feeding of oxytetracycline effectively controlled an outbreak of pinkeye. Subconjunctival penicillin treatment, however, was as effective as the longacting formulation for treatment of individual cases of pinkeye.

A cost/benefit analysis was not performed in this study, but the OTC calves gained an average of 6 pounds more than the controls did and 3 pounds more than the Pen group. Whether this increase in weight gain was sufficient to offset the high purchase cost of the oxytetracycline is unclear.

\section{Conclusions}

The findings of these studies suggest that, whenever the prevalence of pinkeye is low (less than 10\%), the disease can be managed effectively by treating affected animals with three daily subconjunctival injections of procaine penicillin $\mathrm{G}$ ( $1 \mathrm{ml}$ per injection). If there is significant difficulty in administering the drug into the ocular tissues, intramuscular injection of a long-acting oxytetracycline formulation $(20 \mathrm{mg} / \mathrm{kg})$ in two doses given 72 hours a part is also effective.

In a widespread epidemic of the disease where the prevalence exceeds $10 \%$ to $20 \%$, or if it is desirable to minimize ocular scarring, the cattle should be "blitz" treated with long-acting oxytetracycline (two injections spaced 72 hours apart, $20 \mathrm{mg} / \mathrm{kg}$ per injection), and then fed oxytetracycline ( 2 grams per head daily for 10 days).

As with all infectious diseases, affected cattle should be removed from the clinically normal animals. Hands and equipment should be washed thoroughly in chlorhexidine solution after each affected animal is examined or treated.

Control of flies with insecticides delivered through backrubbers or dust bags is highly desirable.

Lisle W. George, DVM, Ph.D., is Associate Professor, Department of Medicine, College of Veterinary Medicine, University of California, Davis.

\title{
Supplements evaluated for wintering range calves
}

\author{
John R. Dunbar a Cindy A. Daley $\square \quad$ J.M. Connor \\ Charles B. Wilson $\square$ Charles A. Raguse $\square$ Thomas R. Famula \\ Melvin R. George
}

\section{In two range feeding trials to evalu- ate supplemental nitrogen and/or bypass protein source and stock- ing densities, calves at a low den- sity gained more weight than high- density groups. Dollar return dur- ing the supplementation phase, however, was highest from high- density groups fed a combination of urea and corn gluten meal.}

California annual rangeland forage is generally of poor quality in the fall and in short supply during the winter. During those periods, supplements are typically pro- vided to wintering calves to correct nutrient deficiencies and improve performance, maintain health, and prevent death loss.

Supplemental nutrients may be provided in many forms, the most common being hay, meals, pellets, cubes, liquids, and blocks. Supplements are usually high in nonprotein nitrogen such as urea, which aids fiber digestion and microbial growth. In many situations, however, urea supplementation may not meet the protein requirements of growing calves. Dietary protein may be digested to a variable degree in the rumen or may be entirely degraded. Protein that is not digested in the rumen, called bypass or escape protein, passes to the lower tract and is either digested postru- 
minally or excreted in the feces. The supply of protein to the small intestine consists of the dietary protein that bypasses ruminal degradation plus the microbial protein synthesized within the rumen. Calves fed supplements that contain bypass protein may gain weight faster and more economically than those supplemented with urea.

Increased bypass protein, however, does not ensure increased animal growth, since: (1) microbial synthesis may provide adequate amino acids for growth; (2) bypass protein may be poorly digested in the small intestine; (3) the balance of amino acids in the postruminal protein may be poor; and (4) the energy supply or other nutrients may limit production.

In the past few years, liquid supplements have been based on urea and molasses. Now xanthin gums and clay are being used to suspend small particles such as minerals, natural protein supplements, and other desirable materials in liquid supplements.

We have been conducting studies to determine if steer calves would show a profitable growth response from supplemental nitrogen and/or bypass protein supplied during fall and winter growth of native range pasture. This report presents results from the first 2 years.

\section{Materials and methods}

Liquid supplements were evaluated as potential sources of bypass protein in supplementation programs for stocker calves on annual grasslands at the UCSierra Foothill Range Field Station. We used 144 head of English breed and English crossbred steers averaging about 500 pounds.

Commercially formulated liquid supplement (molasses based mixtures) containing (1) urea, (2) bypass protein, or (3) urea plus bypass protein were used in the study and compared with (4) unsupplemented controls. Based on previous research, corn gluten meal was selected to supply bypass protein. Each of the four treatments was administered at two levels of stocking density: 6 steers were randomly assigned to a low stocking rate (one head per 5.33 acres) and 12 steers to a high stocking density (one head per 2.67 acres).

The experimental area (512 acres of cleared range) was divided into 16 fields, grouped in 4 blocks of 4 fields per block. In defining the blocks, we attempted to group fields that were similar (based on results of previous trials) in forage production characteristics. Animals were then assigned to one of the eight treatment groups at random. There were two replications per treatment. Subsequently, each treatment was assigned to one of the 16 fields so that each treatment appeared twice in each block.

As the trial progressed, animals (and thus treatments) were moved each month from one field to another so that they repeated no

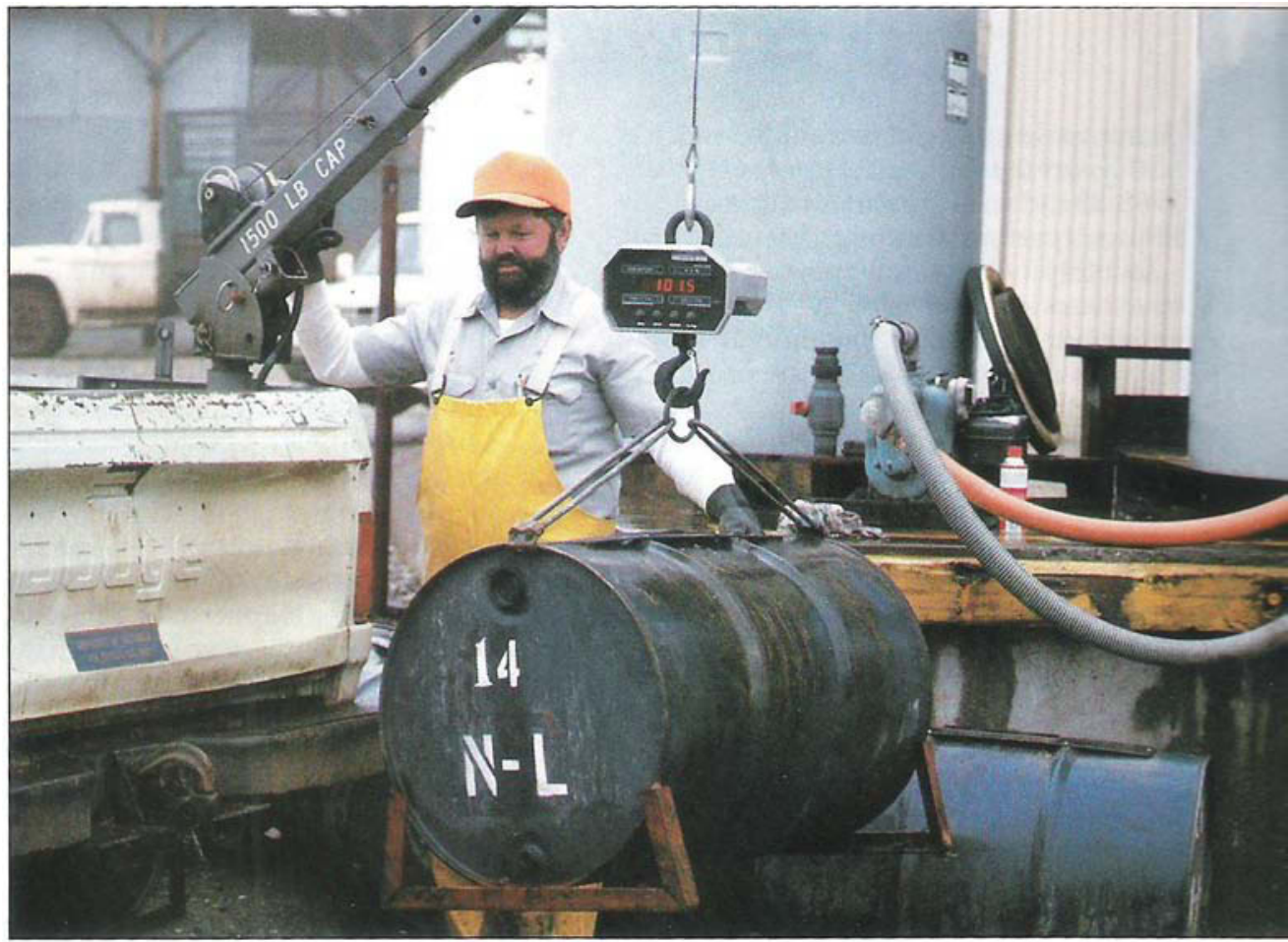

Technician Dave Labadie weighs supplement lick tank to measure consumption by calves.

blocks over the 4-month supplementation period. In this way, each animal was in all four blocks, and each treatment was exposed equally to the various types of range represented in the four blocks. Blocking the fields into groups of four made it possible for each block to contain each treatment in each year of the trial.

Supplement lick tanks were weighed weekly and consumption recorded. Animals were fed on rangelands, followed by finishing under feedlot conditions in 198788 . At the end of the supplementation period in 1988-89, the experimental animals grazed on rangeland during the spring season. A portion of the data was statistically analyzed as outlined by SAS and a portion by CRUNCH.

\section{Results and discussion}

We have collected and analyzed 2 years of data. Consumption was lower during the first month on test and increased as animals became accustomed to the lick tanks (table 1). Consumption was lower in urea-supplemented steers than in the other two groups in 1987-88, but there were no significant differences among groups in 1988-89.

Stocking density had no effect on supplement consumption in either 1987-88 or 1988-89. However, stocking density did affect average daily gain (table 2 ).

The overall performance (cumulative average daily gain) of the steers during the supplemental feeding period is summarized in table 3 . Steers offered supplements containing bypass protein tended to gain more rapidly than did the controls. Table 3 eliminates field bias by reporting cumulative average daily gain occurring over a four-field rotation. Calves fed the urea-corn

\begin{tabular}{|llc|}
\hline \multicolumn{2}{|c}{ TABLE 1. Supplement consumption by month and } \\
treatment
\end{tabular}

NOTE: Duration of supplementation in 1987-88 $=114$ days, $1988-89=111$ days.

- Means in the same column followed by different letters are significantly different $(P<0.05)$.

TABLE 2. Average daily gain by stocking density

\begin{tabular}{|c|c|c|}
\hline \multirow[b]{2}{*}{ Density } & \multicolumn{2}{|c|}{ Average daily gain* } \\
\hline & $1987-88$ & $1988-89$ \\
\hline High & $0.63 a$ & $060 \mathrm{a}$ \\
\hline Low & $0.93 b$ & $0.89 b$ \\
\hline
\end{tabular}

* Means in the same column followed by different letters are significantly different $(P<0.01)$.

TABLE 3. Cumulative average daily gain (ADG) by supplemental treatment

\begin{tabular}{llc}
\hline \hline & \multicolumn{2}{c}{ Average daily gain* } \\
\cline { 2 - 3 } Treatment & $\begin{array}{l}1987-88 \\
11 / 2-2 / 24\end{array}$ & $\begin{array}{c}1988-89 \\
11 / 3-2 / 22\end{array}$ \\
\hline & $\ldots \ldots \ldots \ldots \ldots \ldots \ldots \ldots \ldots \ldots \ldots \ldots \ldots \ldots \ldots \ldots \ldots$ \\
Control & & \\
Urea & $0.63 \mathrm{a}$ & $0.44 \mathrm{a}$ \\
Bypass & $0.74 \mathrm{ab}$ & $0.67 \mathrm{~b}$ \\
Urea + bypass & $0.78 \mathrm{~b}$ & $0.79 \mathrm{bc}$ \\
& $0.96 \mathrm{c}$ & $0.89 \mathrm{c}$
\end{tabular}

- Means in the same column followed by different letters are significantly different $(P<0.01)$. 
gluten meal combination gained more in both years than other treatments. Only in 1988-89 did urea treatment significantly improve performance over that of controls. Monthly average daily gain results for the two stocking rates over all treatments (fig. 1) show more variation than those in table 3 (cumulative average daily gain) because of the short time between weigh periods. The high-stocking-rate groups had a lower average daily gain in both years. The yearly

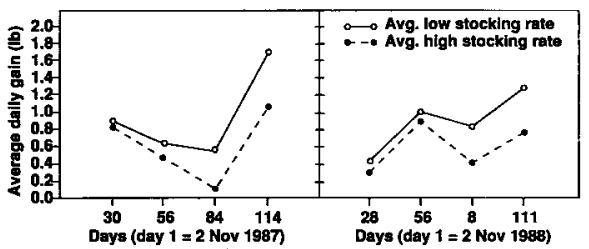

Fig. 1. In both years, average daily gain was higher at the low than the high stocking rate and gradually increased with each weigh period. pattern was somewhat different, but in each year the difference between low and high stocking rate gradually increased through the season.

Results of overall performance and economic analysis of the trial by year (table 4) cover only the period of supplementation. Dollar return per acre favored the steers supplemented with the combination of urea plus corn gluten meal on the high stocking rate in both years.

Because of a drought in the 1987-88 feed year, the experimental animals were continued on supplements from February 24 to March 23, 1988, then shipped to the University of California, Davis, feedlot for finishing. Random subsets of each group were individually fed identical rations for feed intake, compensatory gain, and feed efficiency comparisons. The steers were fed to an estimated slaughter grade of low choice. The supplemental phase treatments had

\begin{tabular}{|c|c|c|c|c|c|}
\hline \multirow{2}{*}{$\begin{array}{l}\text { Supplement, } \\
\text { stocking } \\
\text { rate }\end{array}$} & \multirow[b]{2}{*}{ ADG } & \multirow[b]{2}{*}{$\begin{array}{l}\text { Daily con- } \\
\text { sumption }\end{array}$} & \multirow[b]{2}{*}{$\begin{array}{l}\text { Supplement } \\
\text { cost/head }\end{array}$} & \multicolumn{2}{|c|}{ Return } \\
\hline & & & & $\begin{array}{c}\text { Over } \\
\text { supplement }\end{array}$ & $\begin{array}{r}\text { Per } \\
\text { acre }\end{array}$ \\
\hline & Ib & Ib & $\$$ & $\$$ & $\$$ \\
\hline \multicolumn{6}{|l|}{$\begin{array}{l}\text { 1987-88 } \\
\text { Control }\end{array}$} \\
\hline High & 0.50 & - & - & 48.45 & 18.15 \\
\hline Low & 0.77 & - & - & 74.61 & 14.00 \\
\hline \multicolumn{6}{|l|}{ Urea } \\
\hline High & 0.56 & 1.41 & 10.93 & 43.33 & 16.23 \\
\hline Low & 0.92 & 1.60 & 12.40 & 76.75 & 14.40 \\
\hline \multicolumn{6}{|l|}{ Bypass } \\
\hline High & 0.65 & 1.80 & 20.09 & 42.90 & 16.07 \\
\hline Low & 0.91 & 1.96 & 21.88 & 66.30 & 12.44 \\
\hline \multicolumn{6}{|l|}{ Urea + bypass } \\
\hline High & 0.80 & 2.01 & 22.14 & 55.38 & 20.74 \\
\hline Low & 1.11 & 2.05 & 22.58 & 84.98 & 15.94 \\
\hline \multicolumn{6}{|l|}{$\begin{array}{l}\text { 1988-89 } \\
\text { Control }\end{array}$} \\
\hline High & 0.34 & - & - & 32.30 & 12.10 \\
\hline Low & 0.65 & - & - & 61.20 & 11.50 \\
\hline \multicolumn{6}{|l|}{ Urea } \\
\hline High & 0.55 & 1.62 & 12.30 & 40.00 & 14.80 \\
\hline Low & 0.92 & 1.67 & 12.70 & 74.03 & 13.90 \\
\hline \multicolumn{6}{|l|}{ Bypass } \\
\hline High & 0.74 & 1.95 & 21.70 & 39.54 & 18.00 \\
\hline Low & 0.91 & 1.86 & 20.70 & 65.13 & 12.20 \\
\hline \multicolumn{6}{|l|}{ Urea + bypass } \\
\hline High & 0.78 & 1.70 & 19.80 & 57.55 & 21.60 \\
\hline Low & 1.13 & 1.91 & 22.20 & 84.03 & 15.80 \\
\hline
\end{tabular}

NOTES: $1987-88,114$ days on supplement. $1988-89,111$ days on supplement. Calves valued at $\$ 85 / \mathrm{cwt}$. Cost of supplement/ton: urea $=\$ 136.60 ;$ bypass $=\$ 195.80 ;$ urea + bypass $=\$ 193.20$

TABLE 5. March 23-June 14, 1988, performance in feedlot

\begin{tabular}{|c|c|c|c|c|c|c|}
\hline \multirow{2}{*}{$\begin{array}{l}\text { Supplement, } \\
\text { stocking rate }\end{array}$} & \multicolumn{2}{|c|}{ Weight } & \multirow{2}{*}{$\begin{array}{l}\text { Daily } \\
\text { feed } \\
\text { intake }\end{array}$} & \multirow[b]{2}{*}{ Gain } & \multirow[b]{2}{*}{$A D G$} & \multirow{2}{*}{$\begin{array}{l}\text { Feed/ } \\
\mathrm{lb} / \text { gair }\end{array}$} \\
\hline & Initial & Final & & & & \\
\hline & Ib/head & lb/head & lb & Ib/head & Ib & $1 b$ \\
\hline \multicolumn{7}{|l|}{ Control } \\
\hline High & 583 & 879 & 27.4 & 296 & 3.57 & 7.68 \\
\hline Low & 646 & 948 & 26.8 & 302 & 3.64 & 7.36 \\
\hline \multicolumn{7}{|l|}{ Urea } \\
\hline High & 610 & 882 & 25.9 & 272 & 3.28 & 7.90 \\
\hline Low & 656 & 959 & 27.4 & 303 & 3.65 & 7.51 \\
\hline \multicolumn{7}{|l|}{ Bypass } \\
\hline High & 609 & 928 & 26.1 & 319 & 3.84 & 6.80 \\
\hline Low & 676 & 957 & 27.5 & 281 & 3.39 & 8.11 \\
\hline \multicolumn{7}{|l|}{ Urea + bypass } \\
\hline High & 636 & 902 & 26.1 & 266 & 3.20 & 8.16 \\
\hline Low & 658 & 975 & 27.8 & 317 & 3.82 & 7.28 \\
\hline
\end{tabular}

little influence on finishing phase gains (table 5).

In the 1988-89 trial, urea-supplemented calves gained significantly less than the other treatment groups during the nonsupplemental feeding period on spring range (table6). Table 7 shows the overall performance of the steers during 1988-89. These figures cover only the nonsupplementation period.

Returns over supplement costs were higher per head for the low stocking rate fields because of higher average daily gains. Returns per acre, however, favored the higher stocking densities. Higher cumulative average daily gains resulted in higher returns in 1987-88 than in 1988-89. This result is due in part to differences in residual dry matter of the test fields at the onset of the trial.

\section{Conclusions}

In the two studies of stocking density and protein source in liquid supplements for weaned range calves, performance during the supplementation phase appeared to have little influence on gains during the nonsupplemental phase at feedlot. Steers in the low-stocking-density groups (one head per 5.33 acres) gained more weight than those in the high-stocking-density groups (one head per 2.67 acres) across all supplement treatments. As a result, groups at the lower stocking density returned more dollars per head. Dollar return per acre favored the high stocking density.

The high-density, urea-plus-bypass treatment provided the highest return per acre during the supplementation phase in both years. The cost of supplement used in this analysis does not consider labor expense.

\begin{tabular}{lc}
$\begin{array}{c}\text { TABLE 6. 1988-89 weight gain of steers post-sup- } \\
\text { plementation }\end{array}$ \\
\hline \hline & $\begin{array}{c}\text { Average daily } \\
\text { gain } 1988-89 \\
\text { Treatment }\end{array}$ \\
\hline & $1 / 22-5 / 18$ \\
Control & $2.32 \mathrm{a}$ \\
Urea & $2.05 \mathrm{~b}$ \\
Bypass & $2.40 \mathrm{a}$ \\
Urea + bypass & $2.29 \mathrm{a}$
\end{tabular}

- Means in the same column followed by different letters are significantly different $(P<0.05)$.

TABLE 7. 1988-89 performance of the non-supplementation period ( 85 days average daily gain)

\begin{tabular}{ccc}
\hline \hline $\begin{array}{c}\text { Supplement, } \\
\text { stocking rate }\end{array}$ & $\begin{array}{c}\text { Average } \\
\text { daily gain }\end{array}$ & Gain \\
\hline $\begin{array}{c}\text { Control } \\
\text { High } \\
\quad \text { Low }\end{array}$ & $1 b$ & $1 b$ \\
Urea & 2.15 & 183 \\
$\quad$ High & 1.66 & 226 \\
$\quad$ Low & 2.16 & 169 \\
$\begin{array}{c}\text { Bypass } \\
\text { High }\end{array}$ & 2.26 & 184 \\
$\quad$ Low & 2.47 & 192 \\
$\begin{array}{c}\text { Urea +bypass } \\
\text { High } \\
\text { Low }\end{array}$ & 2.38 & 210 \\
\hline & 2.13 & 196 \\
& & 181 \\
\hline
\end{tabular}

14 CALIFORNIA AGRICULTURE, VOLUME 44, NUMBER 2 
Variations in overall average daily gains between years may be a reflection of residual dry matter differences at the onset of each trial.

John R. Dunbar is Extension Animal Scientist, Department of Animal Science, University of California, Davis; Cindy A. Daley is Staff Research Associate, and John M. Connor is Superintendent, Sierra Foothill Range Field Station, Browns Valley; Charles B. Wilson is Farm Advisor, Sutter-Yuba counties; Charles A. Raguse is Professor, Department of Agronomy and Range Science, UC Davis; Thomas $R$.
Famula is Associate Professor, Department of Animal Science, UC Davis; and Melvin R. George is Extension Range and Pasture Specialist, Department of Agronomy and Range Science, UC Davis.

The authors express their appreciation to Cargill Molasses Liquid Products Division for financial support of the study. The supplements furnished by Cargill Molasses Liquid Products Division are also gratefully acknowledged. During analysis of the data, the authors received valuable assistance from Suzanne Strasser, Senior Programmer, and Heidi A. Johnson, Staff Research Associate, Animal Science Department, UC Davis.

\section{Blue oaks withstand drought}

\section{Douglas D. McCreary}

\section{Many blue oaks in California lost their leaves early in 1987 and 1988 after prolonged periods of low rain- fall. A study found that summer de- foliation had little short-term effect on growth or survival, suggesting that blue oaks are well adapted to withstand periodic droughts.}

In mid-August 1987, many oak trees in California began turning brown and dropping their leaves. While most of the trees affected were deciduous species that normally lose their leaves each year, this event was unusual in that it happened about three months "ahead of schedule." During most years, deciduous oaks don't change color until the short days and cold temperatures of November.

The occurrence of brown trees was widespread, ranging from southern California to the northern portions of the Sacramento Valley. Not all trees were affected, however. In general, dense stands were the most severely affected; trees in clumps or thickets began changing color while most single trees in the open remained green. It also appeared that trees in shallow, rocky soils, or on south-facing slopes, were affected more than those in valleys or swales. One of the principal species affected was Quercus douglasii, commonly called blue oak. This species occurs on vast ranges in the foothills surrounding California's Central Valley.

Because the winter of 1986-87.had been exceedingly dry (fig. 1), and there had been little or no precipitation in much of Califor- nia since March, most observers felt the reason for the trees changing color so early was drought. This is consistent with knowledge of tree physiology. During drought, soil moisture becomes depleted more rapidly than usual, and by midsummer, little is available for plants. By dropping their leaves, trees greatly reduce their moisture requirements, minimizing the potentially disastrous consequences of dehydration.

Oaks have turned brown prematurely before, most recently during the drought of 1976-77. In the summer of 1976, after a dry winter, many oak trees reportedly changed color and lost their leaves early. The following winter was even drier than the preceding one, and many trees had little or no foliage during the next spring and summer. During the following winter,

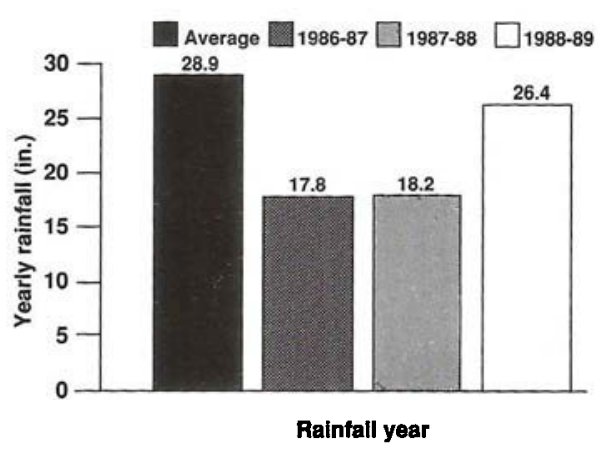

Fig. 1. Yearly rainfall at the field station. The winters of both 1986-87 and 1987-88 were extremely dry. however, when rainfall returned to normal, most trees apparently recovered. By spring, normal growth patterns resumed, and green foliage remained on the trees throughout the summer and into the fall.

Although most oak trees that turn brown early survive and recover the following winter, the effects of drought on the trees are not known. It is reasonable to assume that severe moisture stress prompting leaf loss is not good for trees. Shedding foliage early eliminates the apparatus for photosynthesis. As a result, growth is reduced, and trees may become more susceptible to insect and disease attacks.

Since current photosynthate is also used for acorn development, the loss of foliage before acorns have fully ripened (usually in October) probably retards acorn development and maturity. This may negatively affect wildlife species that rely heavily on acorns for food. It probably also reduces the number of acorns that will become sufficiently mature to germinate in the soil and develop into seedlings.

A study was undertaken to identify some of the effects of drought on blue oak trees. -The goal was to document what happens to trees in the Sierra foothills that turned brown so early in 1987 by monitoring survival, bud burst, and acorn production.

\section{Methods}

Two adjacent 100-tree plots of blue oaks were established in mid-August 1987 at the Sierra Foothill Range Field Station. These plots were selected because the oaks in them varied greatly in degree of browning from healthy looking green trees with abundant foliage to those that had turned completely brown or were bare. There were no obvious site factors such as slope, aspect, or soils to explain the differences in browning. The plots were at an elevation of approximately 600 feet and ranged in size from 0.6 to 1 acre.

Within each plot, all trees larger than 3 inches diameter at breast height (DBH) were tagged with aluminum tags, and sequentially numbered from 1 to 100 . As each tree was tagged, it was assessed for the degree of foliage browning, leaf loss, or both, and given a defoliation rating (table 1).

In September 1987, each tree was evaluated again. DBH was recorded and each tree was given a visual acorn rating according to a standard rating system on a scale of 1 to 4 developed by the California Department of Fish and Game for assessing California oaks (see table 2 footnote). In addition, the percentage of dead branches on each tree was recorded. Each tree was also given a dominance rating indicating whether it was suppressed, intermediate, dominant, or co-dominant.

Starting in February 1988, each tree was evaluated twice a week to determine leaf- 